ISSN 1678-3921

Journal homepage: www.embrapa.br/pab

For manuscript submission and journal contents, access: www.scielo.br/pab
Helio Tonini $(1 \otimes)$

Ciro Augusto de Souza Magalhães ${ }^{(2)}$ and Austeclínio Lopes de Faria Neto ${ }^{(2)}$

(1) Embrapa Pecuária Sul, Rodovia BR-153, $\mathrm{Km} 632,9$, Vila Industrial, Zona Rural, Caixa Postal 242, CEP 96401-970 Bagé, RS, Brazil.

E-mail: helio.tonini@embrapa.br

(2) Embrapa Agrossilvipastoril, Rodovia dos Pioneiros, MT-222, Km 2,5, Zona Rural, Caixa Postal 343, CEP 78550-970, Sinop MT, Brazil.

E-mail: ciro.magalhaes@embrapa.br, austeclinio.farias@embrapa.br

$\bowtie$ Corresponding author

Received

March 13, 2018

Accepted

June 27, 2019

How to cite

TONINI, H.; MAGALHÃES, C.A. de S.; FARIA

NETO, A.L. de. Technical thinning age

of eucalyptus trees grown in crop-forest

integration systems. Pesquisa Agropecuária Brasileira, v.54, e00648, 2019. DOI: https://doi. org/10.1590/S1678-3921.pab2019.v54.00648.

\section{Technical thinning age of eucalyptus trees grown in crop-forest integration systems}

\begin{abstract}
The objective of this work was to determine indicator methods that help to establish the first thinning age of trees to be used in crop-livestock-forest integration systems based on the relationships between eucalyptus growth and soybean and corn production. The experiment followed a completely randomized block design, with four replicates and three production systems (crop monoculture, forest planting monoculture, and crop-forest integration). The percentage of entries and Veiga's methods, as well as the target growth rates, were assessed to set the thinning age to be adopted for integration systems. The percentage of entries method, the age of the maximum mean annual volume increase, or tree age when diameter growth stagnation occurs did not prove adequate as a reference for thinning, when yields of agricultural crops are not jointly monitored. Methods focusing on controlling the basal area and target diameter increase are feasible to define the technical age for thinning implementation and control.
\end{abstract}

Index terms: agroforestry systems, land equivalent ratio, percentage of entries method, Veiga's method.

\section{Idade técnica do desbaste para eucalipto em sistema de integração lavoura-floresta}

Resumo - O objetivo deste trabalho foi determinar métodos indicadores que ajudem a estabelecer a idade do primeiro desbaste para as árvores em sistemas de integração lavoura-pecuária-floresta, com base nas relações entre o crescimento do eucalipto e a produção de soja e milho. O delineamento experimental utilizado foi o de blocos ao acaso, com quatro repetições e três sistemas de produção (lavoura em monocultivo, plantio florestal em monocultivo e integração lavoura-floresta). Para a determinação da idade do desbaste nos sistemas de integração, foram avaliados os métodos dos ingressos percentuais e de Veiga, bem como a taxa de crescimento meta. O método dos ingressos percentuais, a idade do máximo incremento anual em volume ou a idade da árvore quando ocorre a estagnação do incremento diamétrico não se mostram adequados como referência para desbastes, quando a produtividade agrícola não é monitorada de forma conjunta. Os métodos fundamentados no controle da área basal e do incremento diamétrico meta são viáveis para definir a idade técnica de realização e controle dos desbastes.

Termos para indexação: sistemas agroflorestais, razão de área equivalente, método de ingressos percentuais, método de Veiga.

\section{Introduction}

Silvipastural and agrosilvipastural systems comprising eucalyptus trees stand out as a dynamic proposition to integrated and sustainable 
soil management processes focused on timber, grains, meat, or milk production in a single area (Macedo et al., 2015).

Trees work as windbreaks and can help with the control of erosion processes, as well as they conserve and improve soil microclimate and physicochemical properties in integration systems. However, they compete with crops for environmental resources, such as light, water, and nutrients, and such competition may obliterate the potential benefits from these systems (Reynolds et al., 2007; Mugunga et al., 2017).

Bertomeu (2012) suggested alternatives to increase the financial viability of agricultural crops grown in agroforestry systems. Examples of such alternatives concern the increasing of distances between tree rows, properly selecting forest and agricultural species, and adopting silvicultural techniques such as thinning and pruning.

Thinning is one of the main tools used to manage forest species. It is adopted to manipulate the competition between trees, and to concentrate the production increase in a small number of individuals remaining in the field until the final cut (Schneider \& Schneider, 2008). Thus, thinning procedures help to increase usable timber production during the forest stand rotation, as they make more space available for the remaining trees to grow (Ashton \& Kelty, 2018). Moreover, these procedures control the competition between forest species and agricultural and forage crops, maximizing the overall yield and system profitability.

One of the biggest issues regarding thinning process definitions lie on identifying the time when the competition between trees should begin, since the aforementioned technique should be applied a few months before such competition starts (Paiva \& Leite 2015). The technique should be applied before significant losses in the overall yield of the system are recorded in integration systems.

The correct age to proceed with the first thinning in forest stands is to set it through silvicultural criteria combined with professional experience (Schneider $\&$ Schneider, 2008). However, the adopted criterion should be directly, or indirectly, associated with the diameter or volume growth rate (site quality), in order to allow of the identification of the growth stagnation age. According to Ashton \& Kelty (2018), the diameter growth rate is the simplest and the best criterion to determine the thinning time, and its application requires the setting of the target growth rate, as well as the performing of thinning procedures when this rate is no longer met. The method presented by Veiga (1962) lies on adopting the aforementioned principle, which depends on continuous forest inventories to define the growth rate in the basal area. This rate is expressed through the mean square diameter, and thinning is performed as soon as it becomes lower than $15 \%$.

Based on Reis et al. (2014), the maximum age for the mean annual increment (MAI) in volume may also be the reference for shallow cuttings or thinning applications. This criterion derives from the competition between trees, which is already established when the tree population reaches maximum MAI, that is, mean yield matches the growth rate after the competition was already established.

Diameter-growth stagnation time, basal area, or volume, can also be found by monitoring the tree diameter distribution over the years. The method of percentage of entries takes into consideration the population growth dynamics based on the successive entry of trees into new diametric classes. The thinning time corresponds to the age at which the entry of trees into new diameter classes is no longer significant (Leite et al., 2005).

Eucalyptus, soybean, and corn account for most of the cultivated areas in the country due to their economic potential; thus, it is extremely important to match their simultaneous cultivation (Macedo et al., 2015), in order to optimize land use, profitability of the systems, and environmental gains deriving from the trees.

The objective of this work was to determine indicator methods that may help to establish the first thinning age of trees to be used in crop-livestockforest integration systems, based on the relationships between eucalyptus growth and soybean and corn production.

\section{Materials and Methods}

Data were collected during the experiment carried out in October 2011, in the experimental field of Embrapa Agrossilvipastoril, in the municipality of Sinop ( $11^{\circ} 51^{\prime} \mathrm{S}, 55^{\circ} 35^{\prime} \mathrm{W}$, at $370 \mathrm{~m}$ altitude), in the state of Mato Grosso, Brazil. The climate of the region is Aw; with $25.6^{\circ} \mathrm{C}$ annual mean temperature, 1,974 
mm annual mean rainfall, dry period from May to September, and $284 \mathrm{~mm}$ accumulated water deficit (Souza et al., 2013). The soil in the experimental area is classified as a clayey dystrophic Latossolo VermelhoAmarelo, according to the Brazilian soil classification system (Santos et al., 2013), and it is distributed on a flat terrain.

The experiment followed a completely randomized block design, with four replicates, to evaluate the following production systems: SBC, soybean and corn monocultures; F, forest planting monoculture; and CFI, crop-forest integration.

In the SBC, soybean was grown in the summer, followed by intercropping between off-season corn and Urochloa brizantha 'Marandu' (for straw formation purposes). In the $\mathrm{F}$ system, eucalyptus (Eucalyptus urograndis clone H13) was grown in 3.5 $\times 3.0 \mathrm{~m}$ spacing (952 trees ha-1). The CFI system was composed of triple eucalyptus (Eucalyptus urograndis clone H13) rows spaced at $30 \mathrm{~m}$ between rows $\times 3.0 \mathrm{~m}$ between trees $\times 3.5 \mathrm{~m}$ between rows and the soybean crop (SBC).

The experimental units comprised 1 ha covered with monocultures $(100 \times 100 \mathrm{~m})$, and 2 ha covered with crops of the integration system $(200 \times 100 \mathrm{~m})$.

Trees were planted in three-plant rows by adopting East-West orientation and $30.0 \times 3.5 \times 3.0 \mathrm{~m}$ spacing (initial density of 270 trees $\mathrm{ha}^{-1}$ ). The fertilization consisted of $350 \mathrm{~kg} \mathrm{ha}^{-1}$ of simple superphosphate applied to the planting furrow. Cover fertilization with 100 g NPK 20-00-20 per plant was conducted 30 days after planting, whereas $40 \mathrm{~g}$ N-P-K 20-05-20 m-1 (linear) was applied one year after planting.

Soybean was sown in mid-October, and the harvest was carried out in late February in all five years of evaluation. Corn was sown right after the soybean harvest, and was harvested in July. Spacing between rows in soybean and corn cultivations was of $45 \mathrm{~cm}$. The seeder used in the experiment had $4.95 \mathrm{~m}$ planting range width; thus, $24.75 \mathrm{~m}$ were cultivated between rows. Therefore, the mean distance between the first row in the agricultural crops and the external row in the eucalypt tree rows was $2.60 \mathrm{~m}$.

Grain yield in SBC was evaluated by manually by collecting two $5 \mathrm{~m}$ rows of samples, with three subsamples. CFI samples were collected in six different sampling points, on a transect line, at 4.0, 7.5 , and $15 \mathrm{~m}$ distances in the northern and southern sides of the field. Three subsamples were collected in each sampling point. Mechanical threshing, grain mass and moisture calculation, as well as the grain mass correction at $13 \%$ moisture, were carried out after harvest.

Tree growth and yield data of the F and CFI systems were collected in 24 permanent plots (20 in CFI, 4 in F), which were measured when trees were 10, 20, 32, 48 , and 56 months old. The CFI plots comprised three tree rows -81 plants, in total $\left(882 \mathrm{~m}^{2}\right)$ - located in the center of the central row. Plots of the same size as the ones in CFI were installed in the center of each experimental unit in the F system.

Tree trunk diameter was measured in centimeters, $1.30 \mathrm{~m}$ from the base (DBH - diameter at breast height), with the aid of a diameter tape, whereas the total height of all trees $(\mathrm{H})$ was measured in meters, with the aid of an electronic hypsometer. Basal area (1) and volume (2) were measured in $\mathrm{m}^{2}$ and $\mathrm{m}^{3}$ (individually and per unit of area), respectively.

$\mathrm{BA}=\pi \mathrm{d}^{2} / 4$

$\mathrm{v}=\mathrm{ghf}$

in which the terms of the equations mean: BA, individual basal area $\left(\mathrm{m}^{2}\right)$; $\mathrm{d}$, diameter measured at $1.30 \mathrm{~m}$ from the soil $(\mathrm{cm})$; $\mathrm{h}$, total height $(\mathrm{m})$; $\mathrm{f}$, artificial form factor.

The artificial form factor was found by measuring the volume of medium-sized trees that were selected based on the mean square diameter. Sixteen trees were cut at 27 years of age, taking as reference the sample trees of the study of Tonini et al. (2019), and other sixteen trees were cut at 48 months of age. Only medium-sized trees in the CFI system were selected based on the block, on their position in the rows, and on their exposure to the sun.

Thus, three medium-sized trees per year, and per block, were cut: one in the northern row, one in the central row, and one in the southern row. Four trees in the F system were cut in each occasion, and one tree was cut in each block.

The percentage of entries method (PEM) described by Nogueira et al. (2001), the method by Veiga (1962), and the target growth rate by Ashton \& Kelty (2018) were adopted to set the technical thinning age.

The Weibull frequency distribution model (3) was adjusted to each sample unit in the CFI system by 
using the percentile method. It was performed to allow of the determination of the entry at ages older than those recorded in the last measurement.

$$
f(x)=\gamma / \beta(x-\alpha / \beta)^{y-1} \exp -(x-\alpha / \beta)^{Y} \text {, for } x>\alpha, \gamma>0 \text { (3), }
$$

in which the terms of the equation stand for: $\mathrm{x}$, diameter class center; $\alpha$, location parameter; $\beta$, scale parameter; Y, shape parameter.

Subsequently, distribution parameters were estimated through the parameter recovery technique, whereas the equation systems by Leite et al. (2005) was used to design future diameter distributions.

Diameter distributions were designed for each sample unit up to 92 months of age. They took into consideration the technical age from 30 to 88 months for the first thinning in eucalyptus species (Monte et al., 2009; Nogueira et al., 2001; Leite et al., 2005; Binoti et al., 2010; Dobner Jr. et al., 2012). The differentiating diameter and the percentage of entries were calculated based on Nogueira et al. (2001), and divided by the age (months) in order to find the mean monthly percentage of entries (MPE). According to Leite et al. (2005), MPE helps better characterizing the linear and exponential phases, as well as makes it easier to adjust the expolinear model (4). Such model allows of the determination of the technical thinning age, since it enables the estimation of the technical thinning age (TTA) parameter. The Levenberg-Marquardt algorithm was used to adjust the aforementioned model:

$\mathrm{MPE}=\mathrm{b}_{1} / \mathrm{b}_{2} \ln \left[1+\mathrm{e}^{\left(\beta_{2}(\mathrm{t}-\mathrm{TTA})\right)}\right]+\varepsilon$

in which: MPE is the monthly percentage of entries; $t$, population age (months); $\beta_{1}$ is the parameter indicating the absolute maximum increase in the percentage entry of trees, in the linear phase of the curve; $\beta_{2}$, is the parameter indicating the maximum relative increase in the percentage entry of trees, in the exponential phase of the curve; TTA is the parameter indicating the moment from the linear to the exponential phase of the curve, corresponding to the technical thinning age; $\varepsilon$ is the random error.

The method by Veiga (1962) defines the growth increase rate $(\mathrm{T})$ in the basal area through the mean square diameter (5); thinning should be performed whenever $\mathrm{T}$ is lower than $15 \%$.

$\mathrm{T}=[\mathrm{D}-\mathrm{d} / \mathrm{D}+\mathrm{d} / 2] \times 100$ in which: $\mathrm{D}$ is the current mean square diameter; and $\mathrm{d}$ is previous mean square diameter.

The target growth rate is obtained by a goal diameter growth rate and thin it down when it is no longer hit (Ashton\& Kelty, 2018). In the current study the target diameter ranged from 50 to $70 \%$ of the current maximum annual increase.

In addition, the biological efficiency of the integration system (Mead \& Riley, 1981) (6) was measured to help with the definition of the thinning time. Land equivalent ratio (LER) was the index used here:

$\mathrm{LER}=\mathrm{L}_{1}+\mathrm{L}_{2}=\gamma_{1} / \mathrm{s}_{1}+\gamma_{2} / \mathrm{s}_{2}$

in which: $L_{1}$ is the land equivalent ratio in crop $1 ; L_{2}$ is the land equivalent ratio in crop $2 ; \gamma_{1}$ is the crop 1 yield in the integration system; $\gamma_{2}$ is crop 2 yield in the integration system; $S_{1}$ is crop 1 yield in the monoculture system; and $\mathrm{S}_{2}$ is crop 2 yield in the monoculture system.

LER measures the relative efficiency of the system in areas subjected to monoculture. LER values higher than 1 indicate an overall biological advantage in land use efficiency in the integration system, in comparison to the monoculture system.

The fit of models used in the current study was assessed through the coefficient of determination $\left(\mathrm{R}^{2}\right)$, which was calculated based on Kvålseth, recommended to studies focused on assessing the fit of linear and nonlinear models. The standard error of the estimate $\left(\mathrm{S}_{\mathrm{YX}} \%\right)$ was also used in the experiment. Both calculations were described by Môra et al. (2014). The significance of parameters in the nonlinear models was assessed through the confidence interval at 5\% probability. Additionally, the T test was used to assess the significance of parameters in the linear models. Pearson's correlation coefficient was used to assess tree height and basal area effects on the agricultural yield.

\section{Results and Discussion}

The target increment was calculated based on 50, 60 , and $70 \%$ of the current annual increment in the maximum diameter (which happened for 20-monthold trees), and set in 3.6, 3.1, and $2.6 \mathrm{~cm}$ (Table 1). These values are realistic in comparison to those recorded in the literature, since there are no published 
data on this genetic material when plant is grown in the edaphoclimatic conditions found in the municipality of Sinop, in the state of Mato Grosso, Brazil. Data recorded on the diameter increase agree with the results by Reis et al. (2014), who stated that the maximum growth rate in eucalyptus plantations occurs for trees between 18 and 30 months of age.

The equation system used to estimate the number of trees and the percentage of entries in each sampling unit at 20,32, 44, 56, 68, 80, and 92 months of age was:

$$
\begin{array}{ll}
\mathrm{N}_{2}=\mathrm{N}_{1} \exp ^{\left(-423.88\left(\mathrm{I}_{2}^{0.001}-\mathrm{I}_{1}^{0.001}\right)\right)} & \mathrm{R}^{2}=15.4, \operatorname{Syx} \%=19.8 \\
\mathrm{D}_{\min 2}=\mathrm{D}_{\min 1} \exp _{2}^{\left(\mathrm{I}^{0.255}-\mathrm{I}_{1}^{0.255}\right)} & \mathrm{R}^{2}=52.5, \operatorname{Syx} \%=19.6 \\
\mathrm{D}_{\max 2}=\mathrm{D}_{\max 1} \exp ^{\left(520.59\left(\mathrm{I}_{2}^{0.001}-\mathrm{I}_{1}^{0.001}\right)\right.} & \mathrm{R}^{2}=36.2, \operatorname{Syx} \%=12.98 \\
\gamma_{2}=\gamma_{1} \exp ^{\left(3,405\left(\mathrm{I}_{2}^{-0.307}-\mathrm{I}_{1}^{0.307)}\right)\right.} & \mathrm{R}^{2}=85.7, \operatorname{Syx} \%=17.3 \\
\mathrm{~B}=-14.26+9.26 \ln \gamma & \mathrm{R}^{2}=0.92, \operatorname{Syx} \%=9.7
\end{array}
$$

in which: $\mathrm{N}_{1}$ is the number of trees per hectare in one current age; $\mathrm{N}_{2}$ is the number of trees per hectare in one future age; $I_{1}$ is the current age in months; $I_{2}$ is the future age in months; $\mathrm{D}_{\min 1}$ is the minimum diameter at a current age, in $\mathrm{cm}, \mathrm{D}_{\min 2}$ is the minimum diameter at a future age, in $\mathrm{cm} ; \mathrm{D}_{\max 1}$ is the maximum diameter at a current age, in $\mathrm{cm} ; \mathrm{D}_{\max 2}$ is the maximum diameter at a future age, in $\mathrm{cm} ; \gamma_{1}$ is the shape parameter of the Weibull function at a current age; $\gamma_{2}$ is the shape parameter of the Weibull function at a future age, scale parameter of the Weibull function.

The equation to obtain the scale parameter (B) was obtained in the present study, since there was not a good fit for the models suggested by Leite et al. (2005) and Nogueira et al. (2006).

Table 1. Dendrometric data on the forest component (eucalyptus) in the crop-forest integration system with Eucalyptus urograndis clone $\mathrm{H} 13$ and soybean in the summer, followed by intercropping between off-season corn and Urochloa brizantha 'Marandu'.

\begin{tabular}{lcccccc}
\hline $\begin{array}{l}\text { Age } \\
\text { (month) }\end{array}$ & $\begin{array}{c}\mathrm{Dg} \\
(\mathrm{cm})\end{array}$ & $\begin{array}{c}\mathrm{H} \\
(\mathrm{m})\end{array}$ & $\begin{array}{c}\mathrm{BA} \\
\left(\mathrm{m}^{2} \mathrm{ha}^{-1}\right)\end{array}$ & $\begin{array}{c}\mathrm{MAI} \\
\left(\mathrm{m}^{3} \mathrm{ha}^{-1}\right)\end{array}$ & $\begin{array}{c}\mathrm{T} \\
(\%)\end{array}$ & $\begin{array}{c}\mathrm{CAI}_{\mathrm{d}} \\
(\mathrm{cm})\end{array}$ \\
\hline 10 & 2.4 & 2.5 & 0.10 & 0.19 & - & 2.39 \\
20 & 7.5 & 6.8 & 1.09 & 2.37 & 104.0 & 5.17 \\
32 & 11.6 & 12.2 & 2.42 & 5.47 & 43.5 & 4.09 \\
44 & 15.6 & 15.4 & 4.11 & 7.35 & 29.1 & 3.91 \\
56 & 17.6 & 18.3 & 5.11 & 8.33 & 12.4 & 2.00 \\
\hline
\end{tabular}

$\mathrm{Dg}$, mean square diameter; $\mathrm{h}$, mean height; $\mathrm{BA}$, basal area; MAI, mean annual increment; $\mathrm{T}$, diameter growth rate; $\mathrm{CAI}_{\mathrm{d}}$, current annual increment of diameter.
The designed diameter distribution (Figure 1) conforms to a pattern in homogeneous forest planting systems; curves flattened as they moved to the right because of the increased number of trees in the largest diametric classes, and because of the progressive decrease in the entry of trees in new diametric classes.

The most significant entries were recorded up to the age of 44 months (Figure 1). There was a gradual reduction of entries from this age on, although it was not significant until 92 months. The evolution of the monthly percentage of entries related to age (Figure 2) was not so abrupt in comparison to that recorded by Leite et al. (2005) for eucalyptus monocultures.

The aforementioned pattern may be justified by the larger spacing between trees adopted in crop-forest integration (CFI) systems. Higher growth rates were also expected for trees in agricultural areas with highsoil fertility than in marginal areas often used for forestry purposes (Franchini et al., 2014).

Consequently, it was not possible to find any convergence or significance in the fit of expolinear function parameters such as $\beta 1$ and TTA, which indicated the impossibility of identifying the time when MPE becomes nonsignificant, as well as of accurately defining TTA by applying the MPE methodology.

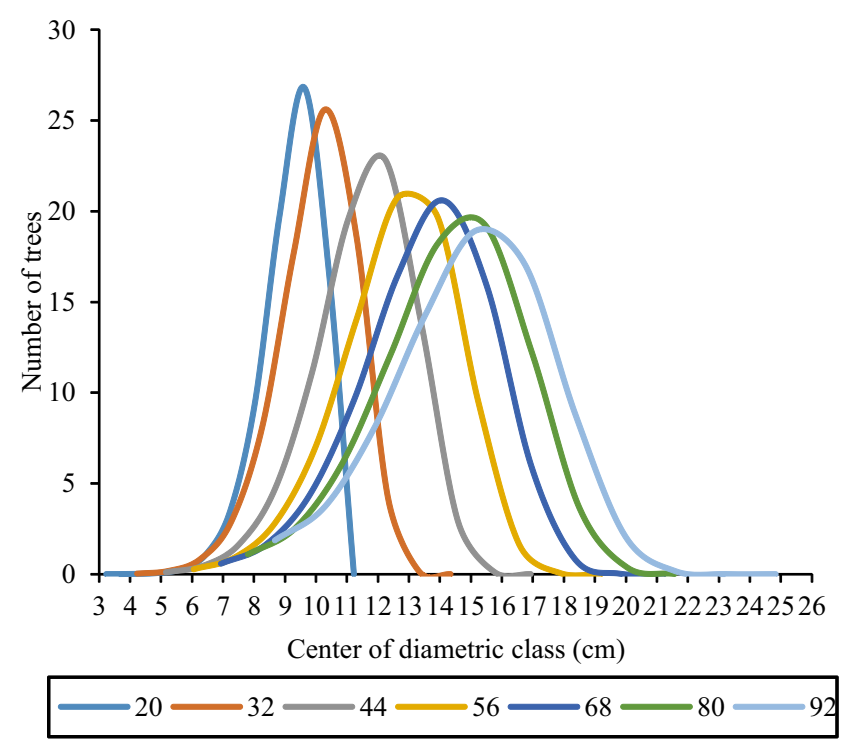

Figure 1. Projected diameter distribution of trees aged from 20 to 92 months in the crop-forest integration system with Eucalyptus urograndis clone $\mathrm{H} 13$ and soybean in the summer, followed by intercropping between off-season corn and Urochloa brizantha 'Marandu' 
$\mathrm{MPE}=-51.76^{\mathrm{ns} /}-0.04 \times \operatorname{In}\left[1+\mathrm{e}^{(-0.01(\mathrm{~T}-129.72 \mathrm{~ns}))}\right]$

$\left(\mathrm{R}^{2}=0.93\right.$, Syx $\left.\%=16.8\right)$

A first thinning at ages greater than 10 years (129 months) would have little biological meaning, since it should start at early ages, as soon as crown competition is established (Ashton \& Kelty, 2018). In monoculture systems, Binoti et al. (2010) recorded a significant decrease in the entry of eucalyptus trees in new diameter classes at 58 months of age. Nogueira et al. (2001) and Leite et al. (2005) applied the MPE to eucalyptus populations, and found a technical thinning age variation from 58 to 88 months. Dobner Jr. et al. (2012), observed that the first thinning in Eucalyptus dunnii stands should be performed when the basal area reaches approximately $20 \mathrm{~m}^{2} \mathrm{ha}^{-1}$ at 3 years of age.

The method of Veiga (1962), used in the present study, made it possible to observe that the technical thinning age (TTA) would lie between 44 and 56 months, since the $\mathrm{T}$ value $(15 \%)$, suggested by the aforementioned author, would lie within the range between such ages (Table 1). However, such age range did not show stagnation in the percentage of entries and in the diameter growth (Figure 3); besides, it did not maximize the mean annual volume increment. This outcome is an indication of no lack of growth space and absence of intense competition between trees, so far.

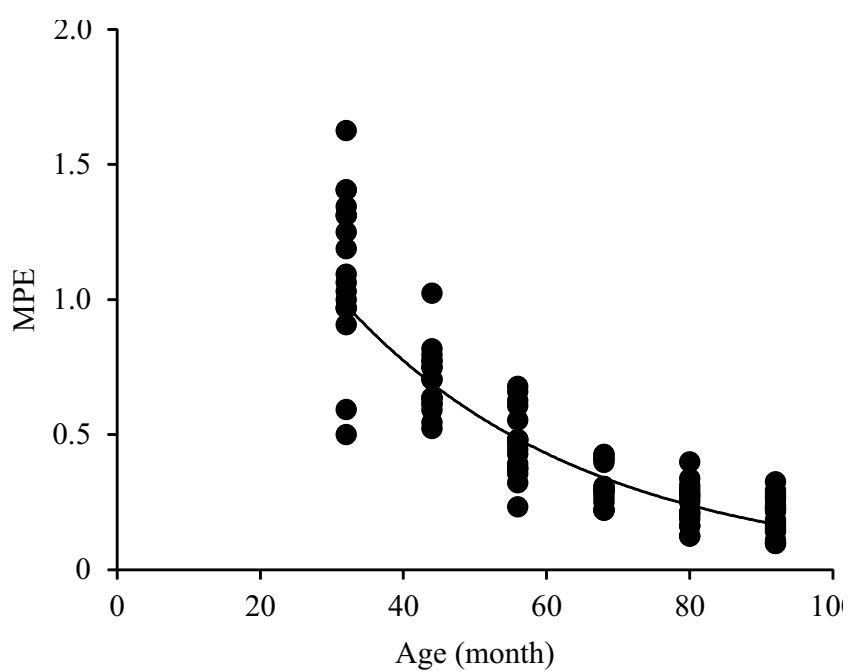

Figure 2. Monthly percentage of entries (MPE) according to age, in the crop-livestock-forest integration system with Eucalyptus urograndis clone H13 and soybean in the summer, followed by intercropping between off-season corn and Urochloa brizantha 'Marandu'.
However, there was a significant reduction of the annual diameter increase between 44 and 56 months (Figure 3). Thus, it was necessary to proceed with thinning in this age range to maintain the target growth rates. At that time, the basal area in the planting system lied between $4.10 \mathrm{~m}^{2} \mathrm{ha}^{-1}$ and $5.11 \mathrm{~m}^{2} \mathrm{ha}^{-1}$.

The age range between 44 and 56 months for TTA lies within the range used for eucalyptus monocultures (36 to 80 months), depending on the site quality (Nogueira et al., 2001; Monte et al., 2009; Dobner Jr. et al., 2012).
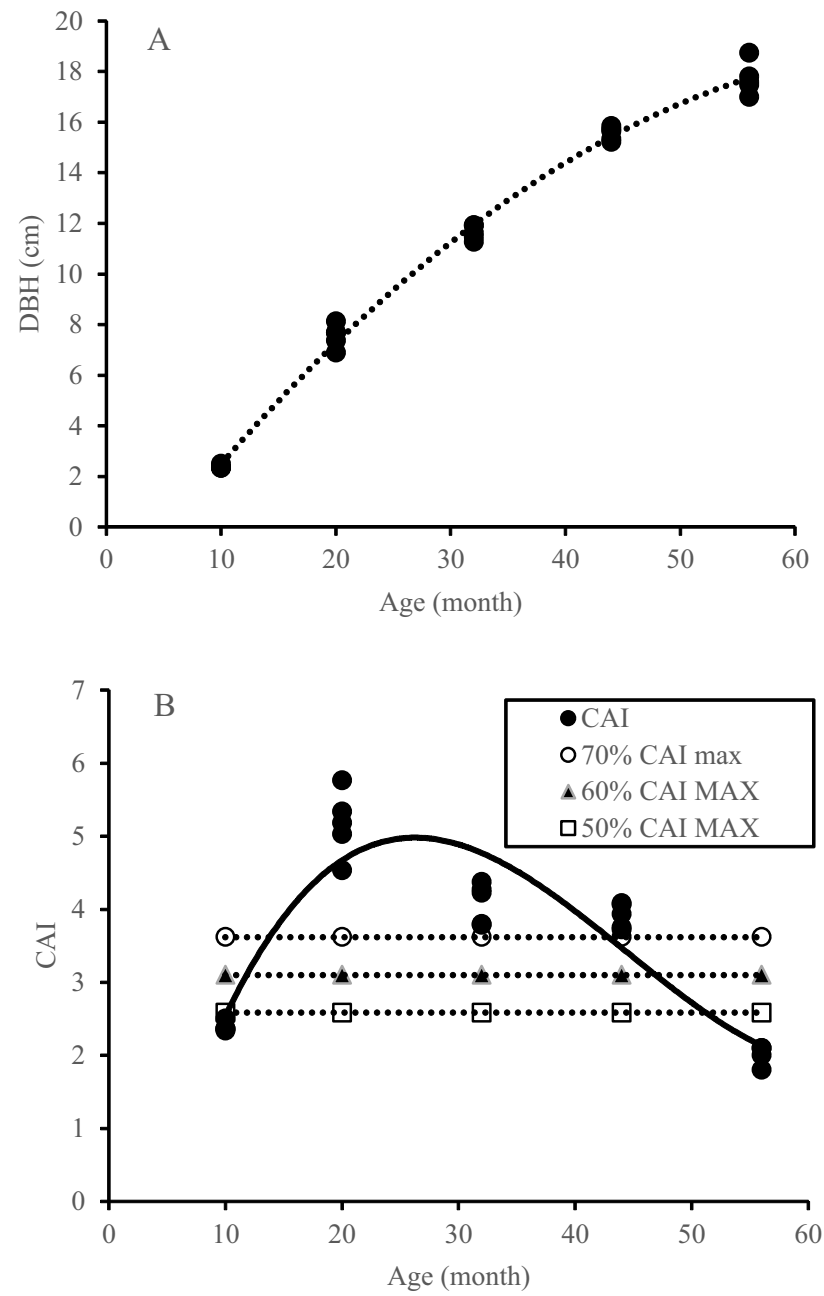

Figure 3. Diameter growth curve (A) and current annual increment (CAI) of diameter, with targets based on the maximum current annual increment (B) of eucalyptus trees grown in the crop-forest integration system with Eucalyptus urograndis clone $\mathrm{H} 13$ and soybean in the summer, followed by intercropping between off-season corn and Urochloa brizantha 'Marandu'. 
There was a significant and negative correlation between corn yield and tree height $(r=-0.95, p=0.015)$, and between corn yield and tree basal area per hectare $(\mathrm{r}=-0.89, \mathrm{p}=0.043)$ up to the age of 56 months. Although the soybean cultivation did not show a significant correlation (height $-\mathrm{r}=-0.68, \mathrm{p}=0.197$; basal area $-\mathrm{r}=-0.77, \mathrm{p}=0.12$ ), the grain production started decreasing from the third harvest on, at the age of 30 months, when trees were $12 \mathrm{~m}$ tall and showed $2.44 \mathrm{~m}^{2} \mathrm{ha}^{-1}$ basal area (Figure 4). Losses relative to
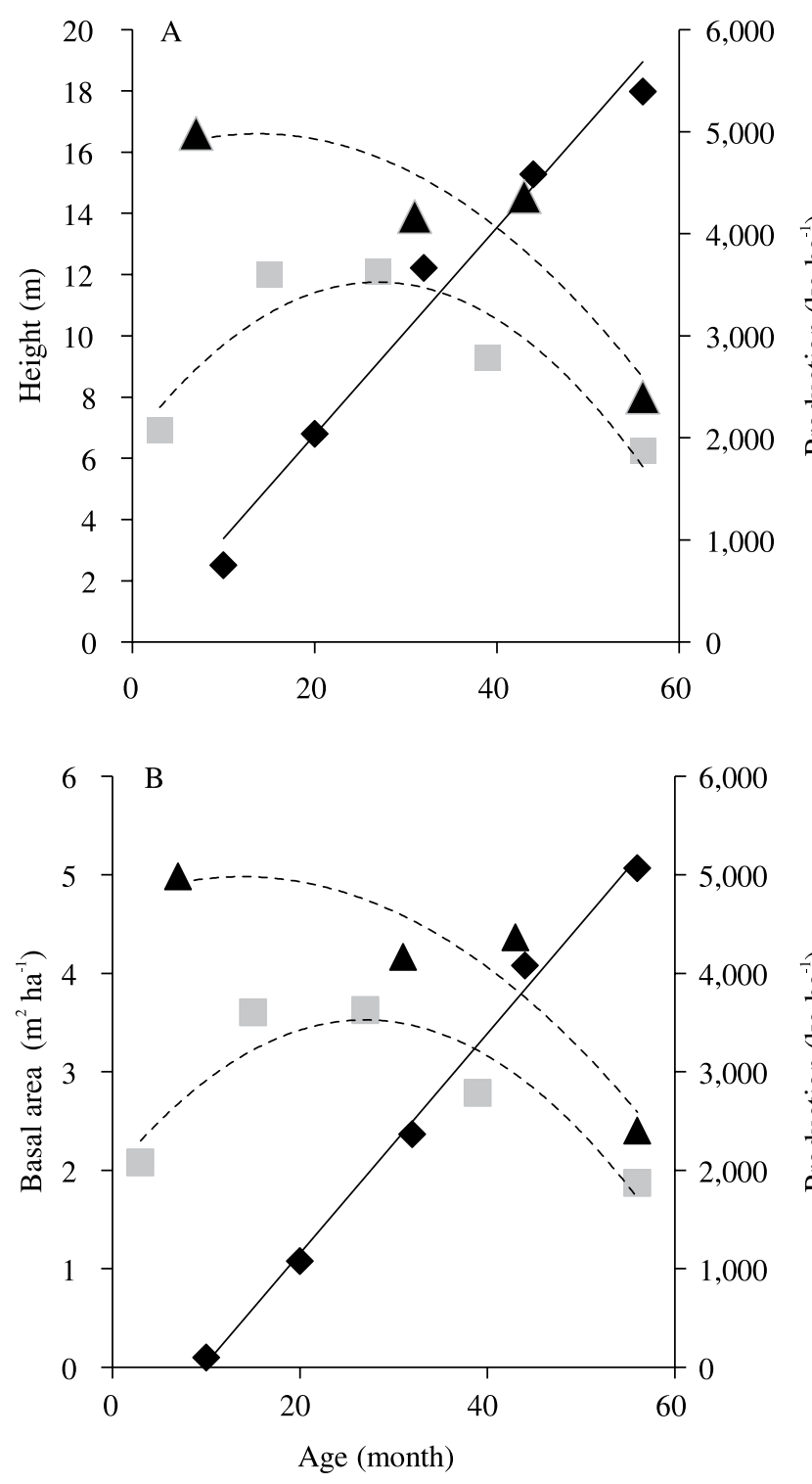

- Basal area Soybean production $\Delta$ Corn production

Figure 4. Grain yield and its relation to height (A), and basal area of trees (B). monoculture system (without tree effect) ranged from 0 to $19 \%$, and increased from the fifth harvest when trees were 56 months old.

The tree shading effect on corn yield was more intense; it led to yield decrease from 0 to $32 \%$, in comparison to the monoculture system. A decreased corn production was recorded in the second harvest (20-month-old trees) and the relative yield was $17 \%$ lower than that recorded for monoculture systems. At that time trees had $6.8 \mathrm{~m}$ mean height and $1.09 \mathrm{~m}^{2} \mathrm{ha}^{-1}$ of basal area. The most significant corn yield reduction was recorded in the fifth harvest, when trees were 56 months old.

The LER value of the CFI system varied from 1.83 to 2.23 , and decreased as the number of harvests increased due to augmentation of tree age and dimensions, and the decreasing of the relative yield of the agricultural crops (Figure 5). However, the overall LER values allow of the stating that the CFI showed a better soil use efficiency than the monoculture during the evaluated cycle.

According to the analysis applied to the LER index components, all integration system components showed a relative efficiency disadvantage in the five harvests. Eucalyptus trees showed 0.25 mean L value, with variations from 0.20 to 0.29 that resulted from the difference in the initial planting density between CFI and F.

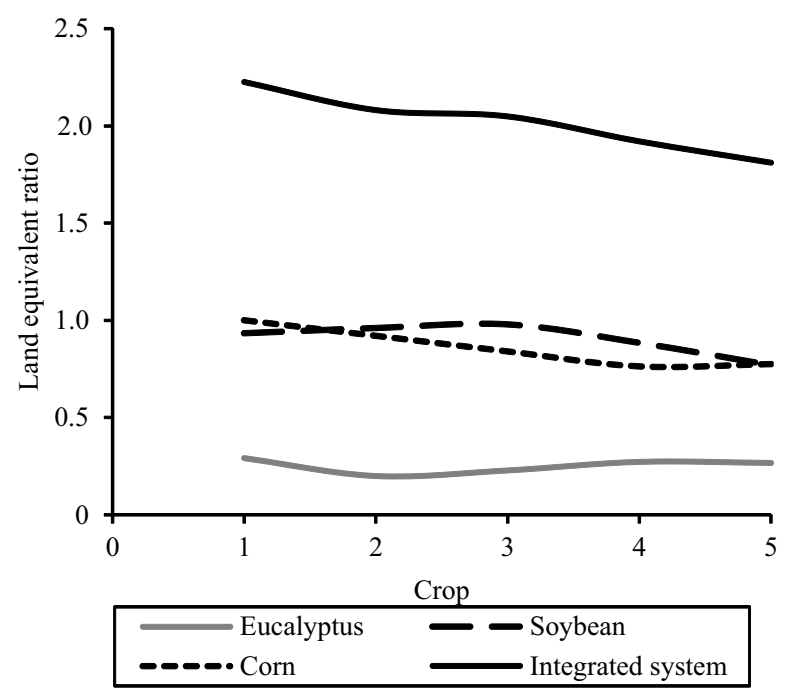

Figure 5. Land equivalent ratio (LER) in the crop-forest integration system with Eucalyptus urograndis clone H13 and soybean in the summer, followed by intercropping between off-season corn and Urochloa brizantha 'Marandu'. 
The $\mathrm{L}$ values recorded for soybean cultivations ranged from 0.77 to 0.93 (mean value 0.91 ), whereas those recorded for corn ranged from 0.76 to 1.0 (mean value 0.86 ) which indicates a lower relative efficiency in corn crops.

The greatest $\mathrm{L}$ reduction of soybean cultivation occurred from the fourth harvest on, whereas the same reduction of the corn cultivation occurred from the third harvest on, which corroborates the TTA defined by the diameter increase data.

Reynolds et al. (2007) also found a soybean production potential higher than that of corn in treeshaded environments. In addition, some studies mentioned that soybean and corn yield decrease in the crop-forest-intercropping systems in comparison to monocultures (Macedo et al., 2006; Bertomeu, 2012; Almeida et al., 2014; Franchini et al., 2014; Mugunga et al., 2017). Soybean yield decrease ranged from 0.04 to $83 \%$ due to the number of assessed harvests. In turn, the number of assessed harvests was directly related to tree growth and planting arrangement for the number of trees in the rows, distance between rows, and spacing between trees in the rows, as well as to differences for growth (vegetative vigor) and for the canopy architecture of forest species, and to the shade tolerance showed by the used cultivar. According to Mugunga et al. (2017), the decreased solar radiation on plants and the competition for water and nutrients in the soil are the main factors responsible for corn yield decrease.

The basal area proved to be a good parameter to indicate the competition between agricultural crops and trees. Soybean losses in the monoculture system were small until the point at which the crop showed $4.1 \mathrm{~m}^{2} \mathrm{ha}^{-1}$ basal area, which indicates the maximum BA value to avoid severe crop yield decreases.

The method of Veiga (1962) and the target growth rate proved to be promising to define the technical thinning age in a soybean-eucalyptus consortium. However, the diameter growth rate used as thinning indicator should not be lower than $29 \%$.

Corn yield decreases were more significant; thus, aspects such as a larger initial spacing between rows and the reduction of the number of rows should be taken into consideration depending on the production priorities, in order to help to minimize such yield decreases.

\section{Conclusions}

1. Methods focusing on basal area and target diameter growth rate controlling are feasible to define the technical age for thinning implementation and control in the integration system.

2. The method of entry percentages, the age of maximum mean annual volume increase, or the diameter-growth stagnation age are not adequate to be used as reference for thinning, when yield of the agricultural crops is not monitored.

\section{References}

ALMEIDA, F.L. de; CALONEGO, J.C.; CATUCHI, T.A.; TIRITAN, C.S.; ARAÚJO, F.F.; SILVA, P.C.G. da. Produtividade de soja em diferentes posições entre renques de eucalipto em cultivo consorciado. Colloquium Agrariae, v.10, p.33-44, 2014. DOI: https://doi.org/10.5747/ca.2014.v10.n1.a098.

ASHTON, M.S.; KELTY, M.J. The practice of silviculture: applied forest ecology. $10^{\text {th }}$ ed. New York: John Wiley \& Sons, 2018. 731p.

BERTOMEU, M. Growth and yield of maize and timber trees is smallholder agroforestry systems in Claveria, northern Mindanao, Philippines. Agroforestry Systems, v.84, p.73-87, 2012. DOI: https://doi.org/10.1007/s10457-011-9444-x.

BINOTI, D.H.B.; LEITE, H.G.; NOGUEIRA, G.S.; SILVA, M.L.M. da; GARCIA, S.L.R.; CRUZ, J.P. da. Uso da função Weibull de três parâmetros em um modelo de distribuição diamétrica para plantios de eucalipto submetidos a desbaste. Revista Árvore, v.34, p.147-156, 2010. DOI: https://doi.org/10.1590/S0100-67622010000100016.

DOBNER JR., M.; HIGA, A.R.; URBANO, E. Determinação da idade e intensidade ótimas para realização do primeiro desbaste em um povoamento de Eucalyptus dunnii. Floresta, v.42, p.485494, 2012. DOI: https://doi.org/10.5380/rf.v42i3.21028.

FRANCHINI, J.C.; BALBINOT JUNIOR, A.A.; SICHIERI, F.R.; DEBIASI, H.; CONTE, O. Yield of soybean, pasture and wood in integrated crop-livestock-forest system in Northwestern Paraná state, Brazil. Revista Ciência Agronômica, v.45, p.10061013, 2014. Número especial.

LEITE, H.G.; NOGUEIRA, G.S.; CAMPOS, J.C.C.; SOUZA, A.L. de; CARVALHO, A. Avaliação de um modelo de distribuição diamétrica ajustado para povoamentos de Eucalyptus sp. submetidos ao desbaste. Revista Árvore, v.29, p.271-280, 2005. DOI: https://doi.org/10.1590/S0100-67622005000200010.

MACEDO, R.L.G.; BEZERRA, R.G.; VENTURIN, N.; VALE, R.S. do; OLIVEIRA, T.K. de. Desempenho silvicultural de clones de eucalipto e características agronômicas do milho cultivados em sistema silviagrícola. Revista Árvore, v.30, p.701-709, 2006. DOI: https://doi.org/10.1590/S0100-67622006000500003.

MACEDO, R.L.G.; VENTURIN, N.; VENTURIN, R.P. Agrossilvicultura do eucalipto. In: SCHUMACHER, M.V.; 
VIEIRA, M. (Org.). Silvicultura do eucalipto no Brasil. Santa Maria: UFSM, 2015. p.187-215.

MEAD, R.; RILEY, J. A review of statistical ideas relevant to intercropping research. Journal of the Royal Statistical Society. Series A, v.144, p.462-509, 1981. DOI: https://doi.org/10.2307/2981827.

MONTE, M.A.; REIS, M. das G.F.; REIS, G.G. dos; LEITE, H.G.; CACAU, F.V.; ALVES, F. de F. Crescimento de um clone de eucalipto submetido a desrama e desbaste. Revista Árvore, v.33, p.777-787, 2009. DOI: https://doi.org/10.1590/S010067622009000500001 .

MÔRA, R.; SILVA, G.F. da; GONÇALVES F.G.; SOARES, C.P.B.; CHICHORRO, J.F.; CURTO, R.D.A. Análise de diferentes formas de ajuste de funções de afilamento. Scientia Forestalis, v.42, p.237-249, 2014.

MUGUNGA, C.P.; GILLER, K.E.; MOHREN, G.M.J. Tree-crop interactions in maize-eucaliptus woodlot systems in shoutern Rwanda. European Journal of Agronomy, v.86, p.78-86, 2017. DOI: https://doi.org/10.1016/j.eja.2017.03.004.

NOGUEIRA, G.S.; LEITE, H.G.; CAMPOS, J.C.C.; SOUZA, A.L. de; COUTO, L. Determinação da idade técnica de desbaste em plantações de eucalipto utilizando o método dos ingressos percentuais. Scientia Forestalis, n.59, p.51-59, 2001.

NOGUEIRA, G.S.; LEITE, H.G.; CAMPOS, J.C.C.; TAKIZAWA, F.H.; COUTO, L. Avaliação de um modelo de distribuição diamétrica ajustado para povoamentos de Tectona grandis submetidos a desbaste. Revista Árvore, v.30, p.377-387, 2006. DOI: https://doi.org/10.1590/S0100-67622006000300008.

PAIVA, H.N.; LEITE, H.G. Desbastes e desramas em povoamentos de eucalipto. In: SCHUMACHER, M.V.; VIEIRA, M. (Org.). Silvicultura do eucalipto no Brasil. Santa Maria: UFSM, 2015. p.83-112.
REIS, G.G. dos; REIS, M. das G.F.; LEITE, H.G.; MONTE, M.A. Desrama artificial e desbaste para produção de madeira serrada. In: VALE, A.B. do; MACHADO, C.C.; PIRES, J.M.M.; VILAR, M.B.; COSTA, C.B.; NACIF, A de P. Eucaliptocultura no Brasil: silvicultura, manejo e ambiência. Viçosa: SIF, 2014. p.283-302.

REYNOLDS, P.E.; SIMPSON, J.A.; THEVATHASAN, N.V.; GORDON, A.M. Effects of tree competition on corn and soybean photosynthesis, growth, and yield in a temperate treebased agroforestry intercropping system in southern Ontario, Canada. Ecological Engineering, v.29, p.362-371, 2007. DOI: https://doi.org/10.1016/j.ecoleng.2006.09.024.

SANTOS, H.G. dos; JACOMINE, P.K.T.; ANJOS, L.H.C. dos; OLIVEIRA, V.A. de; LUMBRERAS, J.F.; COELHO, M.R.; ALMEIDA, J.A. de; CUNHA, T.J.F.; OLIVEIRA, J.B. de. Sistema brasileiro de classificação de solos. 3.ed. rev. e ampl. Brasília: Embrapa, 2013. 353p.

SCHNEIDER, P.R.; SCHNEIDER, P.S.P. Introdução ao manejo florestal. 2.ed. Santa Maria: UFSM, 2008. 566p.

SOUZA, A.P. de; MOTA, L.L. da; ZAMADEI, T.; MARTIM, C.C.; ALMEIDA, F.T. de; PAULINO, J. Classificação climática e balanço hídrico climatológico no estado de Mato Grosso. Nativa, v.1, p.34-43, 2013. DOI: https://doi.org/10.14583/2318-7670. v01n01a07.

TONINI, H.; MORALES, M.M.; SILVA, V.P. da; LULU, J.; FARIAS NETO, A.L. de. Efeito do sistema de plantio e da exposição solar sobre a alocação da biomassa no desenvolvimento inicial do eucalipto. Ciência Florestal, v.29, p.86-95, 2019. DOI: https://doi.org/10.5902/1980509817808.

VEIGA, A. de A. Desbastes de eucaliptos em função da área basal: método de determinação dessa área. Silvicultura em São Paulo, v.1, p.818-827, 1962. 